\title{
Dividend Policy in the Lodging Industry
}

\author{
Linda Canina, Rajesh Advani, Aaron Greenman, and Ifigenia Palimeri \\ Cornell University
}

March 1, 2000

\begin{abstract}
Linda Canina is an assistant professor of finance in the School of Hotel Administration at Cornell University (448 Statler Hall, Ithaca, NY 13853).

Rajesh Advani, Aaron Greenman, and Ifigenia Palimeri are master's students in the School of Hotel Administration at Cornell University.
\end{abstract}

\begin{abstract}
This article analyzes the factors underlying the dividend policy of lodging firms. In addition, it tests whether the market perceives changes in dividends as information about the value of the firm. In a world that is characterized by informational asymmetries between managers and investors, cash dividend payments may be used to convey information from corporate insiders to the company's shareholders. For example, dividend initiations and increases may convey management's confidence that the firm is profitable enough to fund its investment projects and to support the new dividend payment level. An alternative explanation is that dividend initiations and increases may reduce agency costs between managers and shareholders, resulting in an increase in the value of the firm. As a result of cash dividend payments, managers will not invest in negative net-present-value projects. Therefore, the announcement of a dividend initiation or increase should be associated with a stock price increase.
\end{abstract}

Keywords: dividend policy; shareholders; investment; lodging industry. 
Deciding on the amount of earnings to pay out as dividends is one of the major financial decisions that a firm's managers face. U.S. corporations pay out about $50 \%$ of their net income as cash dividends, whereas the lodging industry pays out about7\%of its net income as dividends. In addition, both in the overall market and in the lodging industry, a significant number of corporations pay no cash dividends, and many pay more dividends than their net income. The dividend decision is not obvious. In practice, dividend policy is not well understood. In fact, in the presence of taxes, the payment of a dividend by the firm is regarded as something of a puzzle. ${ }^{1}$

Corporations view the dividend decision as quite important because it determines what funds flow to investors and the funds that are retained by the firm for investment. Dividend policy can also provide information to the stockholder concerning the firm's performance.

The decision to distribute profits as dividends is extremely important in the lodging industry because it is severely cyclical. This analysis of the lodging industry’s dividend policies is important for several reasons that all emanate from the industry's challenging and cyclical market realities. Whereas long-established, government-regulated utility industries have stable profits and more predictable available cash flows for paying dividends, the lodging industry is severely cyclical. From 1988 to 1991, the average annual REVPAR (average daily rate multiplied by occupancy percentage) growth in the U.S. hotel industry declined to $0.06 \%$ after averaging 5.2\% from 1982 to 1987 . Furthermore, there were periods in which average net income of lodging firms was negative. As a result of the high volatility of income, it is difficult for managers to predict a stable dividend level. Excessive dividends may return to haunt a lodging company during an economic downturn, not only disrupting the ability to seize lucrative investment opportunities but also, particularly if the firm is financially distressed, negatively affecting the firm's reputation with the public debt markets. On the other hand, the payment of dividends may increase investors' confidence after a turbulent period. For all these reasons and more, dividend policy of the lodging industry is important. 
Today, most corporations still have to struggle with the following issues related to dividend policy: Should one’s firm's dividend payment be changed or maintained at its current level? If the dividend payment is increased, will profits remain high enough to sustain it? How will the financial market interpret any changes the firm announces regarding its dividend? Do investors prefer a stable dividend payment per share, or is it acceptable to allow payments to fluctuate along with a firm's earnings? Finally, should one's firm's dividend policy favor older investors, who are often retired and prefer a high dividend payout, or younger investors, who face higher marginal tax rates and have a longer investment horizon and thus prefer that profits be invested in the firm rather than being paid out as dividends?

Dividend policy refers to a corporation's choice of whether to pay its shareholders a cash dividend and, if so, how much to pay and how often (annually, semiannually, or quarterly). In addition, dividend policy includes many more variables, such as whether to distribute cash to investors via share repurchases or specially designated dividends rather than regular dividends and how to balance the cash flow preferences of highly taxed individuals with those of the untaxed institutional investors who are becoming increasingly dominant in capital markets around the world.

In this article, we address many of the dividend issues that managers face. For example, we analyze the dividend payout of firms in the lodging industry and compare it to the dividend payout of the financial market as a whole. In addition, we test whether the financial market perceives a change in the dividend policy of the firm to reflect a change in the value of the firm. The empirical test of this model is carried out by examining investors' reaction to the initiation of quarterly cash dividends and the stock price reaction to changes in dividend payments. Last, we compare the financial characteristics of the firms in the lodging industry that pay quarterly cash dividends to those in the industry that do not pay dividends.

We find that the payout ratio is lower in the lodging industry than it is in the market. It is shown that this may be due to the high variability of income and/or the relatively high levels of debt and capital 
expenditure. In addition, we show that very large, highly profitable, stable firms pay dividends in this industry and their managers change dividends slowly over time in response to a change in earnings. Our final result is that investors perceive changes in dividend policy to reflect information about the value of the firm. The initiation of a quarterly cash dividend and an increase in the level of dividends indicate an unexpected increase in the value of the firm.

The remainder of this article is organized as follows. First, we describe the theory of dividend policy. Second, we present the empirical evidence concerning dividend policy. The data sample is described and analyzed in the third section, where we analyze the factors underlying the relatively low payout ratio in the lodging industry relative to the overall market, managers' decisions concerning changes in their policy, the market's reaction to the announcement of dividend initiations and dividend increases, and a comparison of dividend- and nondividend-paying companies in the lodging industry. This is followed by the Conclusion section.

\section{DIVIDEND POLICY THEORY}

If you are responsible for deciding on your company’s dividend payment, you will want to know how dividends affect value. In addition, if dividends affect value, then the attractiveness of a new project may depend on where the money is coming from. For example, if investors prefer companies with high payouts, companies may be reluctant to take on investments financed by retained earnings. The important question is whether the value of the firm is affected by the dividend policy set by managers.

Miller and Modigliani (1961) showed that in perfect and complete markets without transaction costs, agency costs due to incomplete contracts between managers and owners, ${ }^{2}$ taxes, and uncertainty, firms cannot alter their value by changing dividend policy. In this perfect world, it makes no difference whether shareholders receive their cash flows as dividends or capital gains. Dividend policy is irrelevant. It does not affect shareholders' wealth. However, in the real world, where market imperfections such as 
taxes, agency costs, and information heterogeneity exist, the possibility arises that dividends may affect value (see Litzenberger \& Ranaswamy, 1979; Miller \& Scholes, 1978). As a result, dividends are an important decision faced by corporate financial managers.

Currently, there are two theories of dividend policy in which dividends are important in the market's valuation of the firm: the agency cost (contracting) model of dividends and the informational asymmetry (dividend signaling) model. Both models predict a positive relationship between stock prices and dividend changes.

The agency model assumes that dividend payments arise as an attempt to overcome the principle/agent problem that results when there is a separation of corporate ownership and control (see Jensen \& Meckling, 1976; Myers, 1977; and Myers \& Majluf, 1984). When a firm has diffuse ownership, conflicts of interest can arise between stockholders (the principle) and managers (the agent). Jensen and Meckling (1976) suggested that managers of publicly held firms might allocate resources to activities that benefit them at the expense of the shareholders. For example, these activities might include the purchase of corporate jets and unjustifiable acquisitions or expansions. In addition, too much cash in the hands of managers may result in overinvestment. The vast majority of managers prefer to retain free cash flow (cash flow remaining after all positive net present value $[\mathrm{NPV}]^{3}$ projects have been funded) in the firm rather than paying it out to shareholders as dividends. This both increases the amount of resources under management's discretionary control and reduces the risk that the firm will encounter liquidity problems. Such retention by definition implies that funds are invested in negative NPV projects. A partial solution to this problem has been suggested by Easterbrook (1984) and Jensen (1986). If the cash controlled by management is minimized, then the harder it is for them to invest in negative NPV projects. A dividend increase is one way to reduce cash in the hands of managers. Dividends help shareholders control management, thus reducing the conflict between shareholders and managers. Investors understand these incentives and will pay a low price for manager-controlled firms that hoard cash, but they are willing to pay higher prices for stock in companies with managers who pay out cash as dividends rather than hoard 
it. By paying dividends equal to the amount of free cash flow, a firm can reduce management's ability to squander the firm's resources. Therefore, announcements of dividend initiations or increases are associated with stock price increases.

The agency model explains cash dividend payments as value-maximizing attempts by managers to minimize the deadweight costs of the agency conflict between managers and shareholders that arises naturally in public companies where there is a separation of ownership and control. In privately held companies with tight ownership coalitions, these agency costs are not important, so dividends are not needed. As ownership becomes more atomistic, few investors have the incentive or the ability to monitor and control corporate managers, and agency problems become more important. These problems are likely to be more severe in stable, cash-rich companies in mature industries without many growth opportunities.

The assumption behind the competing informational asymmetry model is that dividends exist so that managers, who have a better understanding of the firm's true financial condition than shareholders do, can convey this information to shareholders in a way that will be both believable and harder for weaker firms to duplicate. This model is based on the idea that managers of firms with exceptionally good financial prospects cannot credibly and without cost convey that information to uninformed shareholders, because any costless action they might take—such as publicly announcing the firm's prospects—could also be mimicked by weaker firms. Because investors understand the incentives of weaker firms to mimic stronger ones, they will not believe any public announcement, and all firms will be pooled in investors’ eyes into one average-quality class. ${ }^{4}$

To overcome this market failure, a strong firm has an incentive to employ a signal that would be costly yet affordable for it to employ but would be prohibitively expensive for a weaker firm to mimic. Dividends fit this definition of a signal very well. Cash distributions are costly to the dividend-paying firm, both because the company must generate enough cash to support a permanently high dividend payout and because paying this cash out prevents it from being used to finance positive NPV investment opportunities. Less profitable firms either do not generate enough cash to mimic this dividend payout, 
would find the cost in foregone investment prohibitively expensive, or both. The end result is a separating equilibrium, in which stronger firms employ a signal and are rewarded by a higher stock price, whereas weaker firms choose not to signal and are valued accordingly. This equilibrium is both stable — no party can profit by inappropriate signaling behavior — and efficient, in that the values of all companies correctly reflect their true prospects and investors are able to differentiate strong from weak firms.

In a world that is characterized by informational asymmetries between managers and investors, cash dividend payments serve as a credible transmitter of information from corporate insiders to the company’s shareholders. Viewed this way, every aspect of a firm’s dividend policy conveys significant new information. When a company begins paying dividends (a dividend initiation), this act conveys management's confidence that the firm is now profitable enough to both fund its investment projects and pay out cash. Furthermore, because investors and managers both understand that once a particular dividend payment strategy is initiated it is rarely cut back later, a dividend initiation also implies that management is confident that earnings will be high enough in the future to support the newly adopted payment level.

The same logic applies to dividend increases. Because everyone understands that dividend cuts are to be avoided at almost all costs, the fact that management is willing to increase dividend payments clearly implies it is confident profits will remain high enough to support the new payment level. Therefore, dividend increases suggest a permanent increase in the firm's normal level of profitability. Unfortunately, this logic applies even more forcefully to dividend decreases. Because all concerned understand that dividend cuts are perceived as being very bad news, managers will only reduce dividend payments when they have no choice, that is, when the financial health of the firm is declining and no turnaround is in sight—and the stock market's reaction to dividend cuts is nothing short of foul.

In sum, under agency theory, dividends are good news in that they resolve agency problems. As a result, the expected value of the firm increases as dividends increase. A dividend increase implies that the firm will payout free cash flow to shareholders rather than investing in negative or zero NPV projects. 
Similarly, under the informational asymmetry hypothesis, a dividend increase results in an increase in the market value of the firm. In this case, the dividend increase conveys information from managers to shareholders. An increase in dividends implies that managers expect an increase in earnings. Here, dividends convey good news.

Other market imperfections that influence dividend payments include high transactions costs involved in buying, selling, or issuing securities; the tax treatment of capital gains versus dividend income; and the relative importance of institutional investors in a firm's ownership structure. If dividend payments minimize transactions costs to equity holders, then it may be optimal for firms to pay dividends; if the effective tax rate on dividend income is higher than the tax rate paid on capital gains, then firms should minimize dividend payments; and if some institutions avoid investing in nondividend or low dividend-paying stocks because of legal restrictions, it may be optimal to pay dividends despite the additional taxes levied on individual investors.

\section{REVIEW OF THE EMPIRICAL EVIDENCE ON DIVIDEND POLICY}

There has been much empirical work on dividend policy and the informational role of dividend payments, beginning with John Lintner’s (1956) classic article.

Lintner (1956) conducted a series of interviews with corporate managers about their dividend policies. His work suggested the following:

1. Firms have long-run target dividend payout ratios. Mature companies with stable earnings generally pay out a high proportion of earnings; growth companies have low payouts.

2. Managers focus more on dividend changes than on absolute levels.

3. Dividend changes follow shifts in long-run, sustainable earnings. Managers "smooth" dividends. Transitory earnings changes are unlikely to affect dividend payout. 
4. Managers are reluctant to make dividend changes that might have to be reversed.

They are particularly worried about having to rescind a dividend increase.

Taken together, these observations suggest that most companies had somewhat flexible but reasonably well-defined standards regarding the speed with which they would try to move toward a full adjustment of dividend payout to earnings.

Corporate managers approach dividend decisions with great care and with the idea that the level of dividend payments selected will be a fixed expense of the company for the foreseeable future.

Given his observations, Lintner (1956) suggests that dividend behavior can be described on the basis of the following equation:

$$
\Delta \operatorname{Div}_{i t}=a_{i}+c_{i}\left(\operatorname{Div} *_{i t}-\operatorname{Div}_{i, t-1}\right)+u_{i t}
$$

where

$\Delta D i v_{i t}=$ the change in dividends;

$c_{i}=$ the speed of adjustment to the difference between a target dividend payout and last year's payout;

Div $*_{i t}=$ the target dividend payout, which is a fraction of this period's earnings;

$\operatorname{Div}_{i, t-1}=$ last period's dividend payout; and

$a_{a}, u_{i t}=$ constant and a normally distributed random error term.

Lintner (1956) found that this model explained 85\% of the changes in dividends for his sample of companies. The average speed of adjustment was approximately $30 \%$ per year, and the target payout was $50 \%$ of earnings.

Lintner’s (1956) model suggests that the dividend payment depends on both last year's dividend and this year's earnings. Corporate managers are far more concerned with changing an established per 
share dividend payment than they are with finding the theoretically correct level of dividend payout. This model provides a fairly good explanation of how companies decide on the dividend rate, but it is unlikely to be the whole story. We would also expect managers to take future prospects into account when setting the payment. And that is what we find.

If capital markets are informationally imperfect, Miller and Modigliani (1961) suggested that dividends might convey information about a firm’s prospects. This notion is labeled "the information content of dividends.” The basic intuitive idea in these models is that firms adjust dividends to signal their prospects.

The information-signaling hypothesis contain three important implications about the prospects of the firm that have been tested empirically, as follows:

1. Dividend changes should be followed by subsequent earnings changes in the same direction.

2. Unanticipated changes in dividends should be followed by revisions in the market's expectations of future earnings in the same direction as the dividend change.

3. Unanticipated dividend changes should be accompanied by stock price changes in the same direction.

The evidence about the relationship between dividend changes and subsequent earnings changes is mixed. Watts (1973) was among the first to test the proposition that the knowledge of current dividends improves the predictions of future earnings over and above the knowledge of current and past earnings. He concludes that "in general, if there is any information in dividends, it is very small."

More recent evidence, such as that from Healy and Palepu (1988), indicates that extreme dividend changes contain some information about future changes in earnings. They show that earnings changes following dividend initiations and omissions are at least partially anticipated at the dividend announcement. 
The overall accumulated evidence lends, at best, only weak support to the assertion that dividend changes convey information about future changes in earnings. More encouraging news is found in the second implication of the information/signaling hypothesis. These tests examine the relationship between dividend changes and analysts' forecasts of future earnings. Ofer and Siegel (1987), for example, find that analysts revise their earnings forecast by an amount that is positively related to the size of the announced dividend change. They also provide evidence that the revision is positively correlated with the market reaction to the announced dividend. This result is consistent with the information-signaling hypothesis. It is also consistent with the agency explanation of why firms pay dividends. If higher dividend payouts discipline management, then we may expect better performance by those firms in the future, hence positive price reaction and a like revision in analysts' forecasts.

The third set of tests questions whether the market perceives changes in dividends as conveying new information about the value of the firm. The answer to this question is almost uniformly yes. There are numerous studies that show that dividend changes cause a like change in security prices. For example, Petit (1972) shows that announcements of dividend increases are followed by a significant price increase, and announcements of dividend decreases are followed by a significant price drop. Aharony and Swary (1980) show that these relationships hold even after controlling for contemporaneous earnings announcements. All in all, there seems to be an overall agreement that dividend changes are associated with like changes in stock price.

Lang and Litzenberger (1989) test the agency theory of dividends and contrast it with the information-signaling theory. According to the theory, an increase in dividends should have a larger price impact for firms that overinvest than for firms that do not. They categorized the over investing firms as those with Tobin's Q less than one. ${ }^{5}$ Under the information hypothesis, the impact is not related to overinvestment. They found that dividend changes have a larger effect for firms with lower Q. Their evidence is consistent with the agency theory of dividends. 
Yoon and Starks (1993) repeated the experiment for a longer time period and found that the reaction was symmetric to dividend changes between high and low Tobin's Q firms. Their evidence is inconsistent with the agency theory of dividends.

Bernheim and Wantz (1995) analyze dividend changes during different tax regimes. During periods when taxes on dividends are higher than taxes on capital gains, the information hypothesis implies that the market's reaction to dividend increases should be larger because it is more costly to pay dividends.

The agency model of dividends has the opposite prediction. During periods of higher relative taxes on dividends, the market should react less favorably to dividend increases because the cost to the investor is higher. Their evidence is consistent with the asymmetric information model of dividends.

\section{SAMPLE DESCRIPTION AND EMPIRICAL RESULTS}

\section{Data Sample}

Our sample firms were obtained from the Compustat Data Base maintained by Standard and Poor's (S\&P). Firms were selected if their primary business is in the lodging industry. The following variables were collected on an annual basis from Compustat for each lodging firm and for the S\&P500 market portfolio during the 1976 to 1995 time period: (a) total assets, ${ }^{6}$ (b) capital expenditures, ${ }^{7}$ (c) longterm debt, ${ }^{8}$ (d) net income, ${ }^{9}$ (e) cash dividends, ${ }^{10}$ and (f) dividend payout. The sample contains 32 companies, of which 14 paid quarterly cash dividends for at least $5 \%$ of the time over their sample period. The dividend history of the sample is presented in the appendix. Daily stock prices, stock and cash distributions, stock splits, reorganizations, and the announcement dates of the distributions were extracted from the 1996 CRSP tapes for the sample of Compustat lodging firms during the 1962 to 1996 sample period. 


\section{Results}

In this section, we analyze the dividend policy of the lodging industry and relate it to the existing theoretical and empirical work on dividends. For the stock market as a whole, the following four empirical observations have played an important role in discussions of dividend policy:

1. Corporations typically pay out a significant percentage of their earnings as dividends.

2. Historically, dividends have been the predominant form of payout; share repurchases were relatively unimportant until the mid-1980s.

3. Corporations smooth dividends.

4. The market reacts positively to announcements of dividend increases and negatively to announcements of dividend decreases.

We will discuss each of them in relation to the lodging industry and to the overall stock market. Last, we compare the financial characteristics of dividend-paying firms to nondividend-paying firms in the lodging industry.

\section{Corporations Pay Large Portion of Their Profits as Dividends}

The first observation that corporations pay a substantial portion of their after-tax profits as dividends is illustrated in Table 1 (row 1, column 4). Typically, the average company in the S\&P500 pays 49.88\% of its profits out as dividends. This is consistent with Lintner’s (1956) finding that the target payout ratio is $50 \%$ of earnings. The average dividend payout for the sample of lodging firms is considerably lower at $7.30 \%$ (see Table 1, row 1, column 1). The lower payout could be the result of the relatively high investment requirements, highly volatile income levels, and/or high debt levels. 
Paying dividends to shareholders is a voluntary decision and is one way of distributing excess capital. Although early financial literature has argued that dividend policy should be independent of firm investment decisions, recent studies indicate that linkages are probable in a world of imperfect capital markets. It has been documented that dividends vary positively with earnings but negatively with investment. As a result, it may be rational for firms with large investment requirements to pay low dividends and use the retained earnings for investment purposes. According to this argument, which is known as the "pecking order" theory, companies finance new investments with the cheapest available source of funds. Specifically, they prefer internally generated funds (retained earnings) to outside funding; and if internal funds are insufficient, they prefer debt to equity because of debt's lower flotation and information costs. Under this model, companies issue equity only as a last resort, when their debt capacity is fully exhausted. The data in Table 1 are consistent with this argument. Table 1 shows a negative relationship between investment and dividends. For the S\&P500 market portfolio, capital expenditure as a percentage of total assets is $3.65 \%$, and payout is $49.88 \%$; whereas for the lodging industry, capital expenditure as a percentage of total assets is $11.17 \%$, and payout is $7.30 \%$. As investment increases, dividend payout decreases.

The second factor behind the lower payout may be due to the high volatility of income. We used the standard deviation of the ratio of income to assets as a measure of the volatility of income. The standard deviation of average net income/ total assets for lodging companies is 4.33 and 0.08 for the S\&P500 market portfolio. The higher the volatility of income, the greater is the probability that managers will not have enough cash to cover the promised dividend payment. As a result, given a highly uncertain income stream, managers will set a conservative dividend payout to avoid the embarrassment of having to cut the dividend during periods of low profitability.

The third factor is that a high debt ratio is consistent with a low payout ratio. Debt contracts oblige the firm to make a fixed set of cash payments over the life of the loan. If these payments are not made, there are serious consequences, including bankruptcy. Adding debt to the firm's capital structure 
can serve as a credible signal of high future cash flows. By committing the firm to make future interest payments to bondholders, managers communicate their confidence that the firm will have sufficient cash flows to meet these obligations. If future cash flows are insufficient to cover interest payments, the firm can be forced into bankruptcy and managers may lose their jobs. As the level of interest payments increase, the riskiness of the dividends also increases. As a result, managers prefer a low payout ratio.

In addition, as the level of debt increases, the cost of paying dividends also increases, assuming that the firm has positive NPV projects to invest in, because the financing costs will increase. As the level of debt increases, the cost of raising additional debt and equity also increases. As a result, managers prefer to maintain a low payout ratio. In fact, financial leverage is considerably higher for lodging firms than for the market. The debt to asset ratio for lodging firms is 36.90\%, and for the S\&P500 market portfolio, it is $15.60 \%$.

\section{Dividends Are the Predominant Form of Payout}

The second observation that dividends have been the predominant form of payout is an understatement in the lodging industry. Over the entire sample period, not one share of stock was repurchased by the sample of firms. ${ }^{11}$ This is consistent with the low payout ratio due to high investment needs because repurchases correspond to an increase in the overall level of payouts.

\section{Companies Smooth Dividend Payments}

The third observation is that almost all firms maintain constant nominal dividend payments per share for long periods of time. Put another way, companies tend to "smooth” dividend payments, and these payments show far less variability than do the corporate profits on which they ultimately are based. Managers will not increase per share dividends until they are convinced that "permanent” earnings have 
increased enough to support a higher dividend level, and they will then gradually increase dividend payments until a new share equilibrium payment is reached. Likewise, corporate managers will try to maintain nominal per share dividend payments, even in the face of temporary net losses, until it becomes clear that earnings will not revive. Managers will then reduce (but almost never eliminate) dividend payments and will make the full adjustment in one large cut.

We observe from the appendix that dividends are stable for long periods of time in the lodging industry. Over the 1969-1975 and 1982-1988 periods, Hilton did not make any changes to its quarterly cash dividend payouts. At other times, Hilton slowly increased its dividends. Over the 1965-1969 period, it increased its dividend payments by 5 to 10 cents per year. Marriott gradually adjusted dividends from a level of $\$ 0.04$ /share in 1979 to $\$ 0.35 /$ share in 1989 , with no change from the last quarter of 1989 to their spin-off in 1993. Other companies exhibit similar dividend policies. For example, Club Med announced the initiation of a regular semiannual cash dividend of 10 cents per share on February 13, 1985. It remained at that level until July 9, 1990, when Club Med announced an increase of 5 cents per share. In general, in the lodging industry, dividends are increased gradually and are rarely cut.

This dividend behavior is consistent with that found by Lintner (1956) from his series of interviews with managers. Lintner’s study showed that the behavior of managers to gradually increase dividends and to rarely cut dividends was fairly widespread. He observed that firms are primarily concerned with the stability of dividends. They do not set dividend de novo each quarter. Instead, they first consider whether any change from the existing rate is necessary. Only when they have decided a change is necessary do they consider how large it should be. Managers appear to believe strongly that the market puts a premium on firms with a stable dividend policy.

Second, Lintner (1956) observed that earnings were the most important determinant of any change in dividends. Management needed to explain to shareholders the reasons for its actions and needed to base its explanations on observable indicators. The level of earnings is the most important of these. 
Most companies appeared to have a target payout ratio: If there was a sudden unexpected increase in earnings, firms adjusted their dividends slowly. Firms were reluctant to cut dividends.

Based on these observations, we estimated the following model to see whether lodging managers change dividends in response to changes in earnings and to test statistically whether managers tend to smooth dividends.

$$
\Delta \operatorname{Div}_{i t}=0.1190+0.175 \Delta I n c_{i t}+0.0153 \Delta \operatorname{Inc} c_{i y-1}+0.6616-\operatorname{Div}_{i t-1},
$$

where $\Delta D i v_{i t}$ is the change in dividends this year, $I n c_{i t}$ is the change in income this year, and $t-1$ denotes the change in income or dividends over the previous year. The change in income this year, $\Delta \operatorname{Inc} c_{i t}$ was included because Lintner (1956) observed that earnings were an important determinant of any change in dividends. The change in income and dividends last year, $\Delta I n c_{i t-1}$ and $\Delta D i v_{i t-1}$, respectively, were included because Lintner concluded that managers adjust dividends slowly over time rather than making the full adjustment at once. Each coefficient is significantly greater than zero at the $1 \%$ significance level. Consistent with Lintner's observations, we find that income changes are a major factor in management's decision to change dividends but dividends adjust slowly to changes in income. For example, a \$1 increase in income this period is accompanied by about a $\$ 1.75$ increase in dividends. Rather than fully adjusting dividends in response to a change in earnings, lodging managers adjust dividends slowly over time. This is verified by the significant relationship between the change in dividends this period and the changes in income and dividends from last period. This strategy allows management to become confident that profits have in fact permanently increased before fully committing to higher dividend payments. In this way, it is less likely that they will have to reverse their dividend decision in the future.

\section{Market's Response to Changes in Dividends}

The fourth observation is that the market reacts positively to announcements of dividend increases and negatively to announcements of dividend decreases. This phenomenon was documented by 
many studies such as Petit (1972), Charest (1978), and Aharony and Swary (1980). This evidence is consistent with markets in which managers know more than outside shareholders or when contracts are incomplete. If managers know more than outside shareholders, then dividends are being used by managers to convey information to outsiders. For example, a dividend increase may be the result of an unanticipated earnings increase. Furthermore, if contracts are incomplete, dividends are a means to discipline management to allocate resources to activities that maximize shareholders’ wealth. For example, the less discretionary cash management has, the more difficult it is for management to invest in negative NPV projects. In both cases, where dividends may convey information and dividends are information, dividends help to overcome informational asymmetries in modern capital markets. ${ }^{12}$ Dividend increases imply that management expects higher earnings in the future, whereas decreases imply declining earnings prospects. As a result, the stock market reacts positively to dividend initiations and increases and has a strong negative reaction to dividend decreases or elimination. When a company announces either its first regular cash dividend payment (an initiation) or an increase in its existing per share dividend, that company's stock price typically increases by $1 \%$ to $3 \% .{ }^{12}$ However, firms that cut or eliminate their dividends are severely punished by the stock market, sometimes witnessing stock price declines of up to $50 \%$.

Marriott initiated quarterly cash dividends during the fourth quarter of 1977 when it had an asset base greater than $\$ 870$ million and net income greater than $\$ 35$ million. Its total assets and net income had been growing by $14 \%$ on average over the previous 5 years. At the time of the announcement, there was an unexpected increase in the stock price of about $3 \%$ on a daily basis. The announcement of a dividend initiation by managers was perceived to be good news about the future prospects of the company by investors.

Club Med’s stock price reacted similarly to the announcement of a dividend initiation in February 1985. At that time, it had assets worth $\$ 269$ million and net income of about $\$ 16$ million. Its assets and net income had been growing at an average annual rate of 32\% over the previous 3 years. Marriott and 
Club Med's stock price reaction is typical of the lodging industry’s stock price reaction on the announcement day of a dividend initiation. Table 2 shows the average excess return ${ }^{14}$ for the day before through the day after the announcement of a dividend initiation, in which excess return refers to the unexpected portion of the daily total return. The unexpected return on the day before through the day following the announcement of the initiation is $2.46 \%, 1.96 \%$, and $1.3 \%$, respectively. On the announcement date, the stock price increased by $1.96 \%$ more than investors expected, on average. Each excess return is statistically positive at the $5 \%$ significance level.

Similarly, the market’s reaction to increases in dividends in the lodging industry has been positive, on average. During the second quarter of 1966 and the first quarter of 1967, Hilton announced increases in its quarterly cash dividends, and there was a positive stock price reaction to the news. Across all lodging companies that announced dividend increases, the average excess return was $0.625 \%$ on the announcement date of the dividend increase, as shown in Table 3. This excess return is significantly greater than zero at the $5 \%$ significance level.

\section{The Financial Characteristics of Dividend-Paying Lodging Companies}

Table 4 reports the financial characteristics of dividend- and nondividend-paying companies in the lodging industry. It is clear that, on average, only large, highly profitable companies with stable earnings pay dividends in this industry. The average size, net income to asset ratio, and the volatility of net income are \$876 million, 7.26, and 2.34 for dividend-paying companies. For nondividend-paying companies, the average size is $\$ 90$ million, the average ratio of net income to assets is 0.30 , and the volatility of this ratio is 5.85. Dividend-paying companies have assets worth about 10 times more than the assets of nondividend-paying companies. In addition, the ratio of net income to assets is more than 20 times greater for dividend-paying relative to nondividend-paying companies. And the volatility of net 
income to assets is about half that of the nondividend-paying companies. The debt and capital expenditure levels are insignificantly different across the two groups.

The large, highly profitable, stable companies in this industry are paying dividends at about half the rate as the overall market. In addition, their debt level and capital expenditure levels are high. As a result of the high debt and capital expenditure of the dividend-paying companies, in addition to their similarity to the nondividend-paying firms, it does not seem that dividends are being used by equity holders to deal with a free cash problem, that is, as a tool to limit overinvestment by management.

\section{CONCLUSION}

In frictionless and complete capital markets, firms cannot alter their value by changing dividend policy. Because markets are imperfect, dividends represent one of the most important financial decisions faced by corporate financial managers. The theoretical work on dividends focuses on the impact of market imperfections such as asymmetric information, taxes, transaction costs, and agency costs on dividend policy. This article analyzes the dividend policy set by lodging managers and examines the financial market's reaction to dividend initiations and dividend increases.

Managers view the dividend decision as quite important because it determines what funds flow to investors and what funds are retained by the firm for investment. Dividend policy can also provide information to the stockholder concerning the firm's future performance. An analysis of the lodging industry’s dividend policies is important for several more reasons. First, the lodging industry is severely cyclical. In fact, there were periods in which average net income of lodging firms was negative. As a result of the high volatility of income, it is difficult for managers to predict a stable dividend level. Second, the lodging industry has high investment requirements. Both renovation and expansion are highly dependent on capital availability. As dividend payment increases, less internal capital is available for improvements. 
We found (a) the average dividend payout for lodging firms is less than the payout of the market, in which the low-payout may be due to high investment requirements, highly volatile income, and/or high interest payments; (b) managers change dividends slowly in response to a change in earnings; (c) the stock market reacts favorably to dividend initiations and increases in dividends; and (d) the large, highly profitable, stable companies are paying dividends in the lodging industry.

This work suggests that if managers know more about the true worth of their firm, dividends may be used to convey information to the market. ${ }^{15}$ In addition, if dividends are being used as a device to discipline management, then dividends are information about a reduction in agency costs. As a result, dividend initiations and increases imply an increase in the value of the firm. We present empirical evidence for the lodging industry that is consistent with this theory. Cash dividend payments serve as a transmitter of information from corporate insiders to the company's shareholders. Dividend initiation conveys management's confidence that the firm is both profitable enough to fund its investment projects and pay out cash. Furthermore, because investors and managers both know that once a particular dividend payment strategy is initiated, it is rarely cut back later, a dividend initiation also implies that management is confident that earnings will be high enough in the future to support the newly adopted payment level. Dividend increases suggest a permanent increase in the firm's normal level of profitability. A dividend increase implies that management is confident profits will remain high enough to support the new payment level.

In almost every industry around the world, firms with tightly knit control coalitions tend to have very low-dividend payout, whereas companies with more diffuse ownership structures tend to need higher payouts. Even though the nondividend-paying companies in this sample are publicly traded, they might also be closely held companies and, as a result, do not pay dividends. Furthermore, if they are closely held, there may not be a high degree of information asymmetry between managers and stockholders. Therefore, dividends are not needed as a signaling device. At this point, this is speculation and is an interesting topic for future research. 


\section{NOTES}

1. Taxes work against the payment of dividends, assuming that investors must pay income taxes at their top marginal rate on all cash dividends received but can defer taxes on share price gains for many years.

2. In most corporations, the managers (hired as agents of the owners) are not the owners, and they may be tempted to act in ways that are not in the best interests of the owners. For example, they might engage in empire building or adding excess capacity. The costs of resolving the conflicts of interest between managers and owners are called agency costs. These costs are defined at the sum of (a) the monitoring costs of the owners and (b) the costs of implementing control devices.

3. The net present value (NPV) of a project is the sum of the present values of the expected cash flows on the project, net of the initial investment.

4. The best known of these signaling models are Bhattacharya (1979), Miller and Rock (1985), and John and Williams (1985).

5. Tobins's Q is defined as market value over replacement value.

6. This item represents current assets plus net property, plant, and equipment plus other noncurrent assets (including intangible assets, deferred item, and investments and advances).

7. This item represents cash outflow or the funds used for additions to the company's property, plant, and equipment. This item includes (a) expenditures for capital leases, (b) increase in funds for construction, and (c) reclassification of inventory to property, plant, and equipment. This item excludes (a) capital expenditures of discontinued operations; (b) changes in property, plant, and equipment resulting from foreign currency fluctuations when listed separately; (c) decrease in funds for construction presented as a use of funds; and (d) property, plant, and equipment of acquired companies.

8. This item represents debt obligations due more than 1 year from the company's balance sheet data and includes (a) purchase obligations and payments to officers (when listed as long-term 
liabilities); (b) notes payable, due within 1 year and to be refunded by long-term debt when carried as a noncurrent liability; (c) long-term lease obligations (capitalized lease obligations); (d) industrial revenue bonds; (e) advances to finance construction; (f) loans on insurance policies; (g) indebtedness to affiliates; (h) bonds, mortgages, and similar debt; and (i) all obligations that require interest payments. This item excludes (a) subsidiary preferred stock, (b) the current portion of long-term debt, (c) accounts payable due after 1 year, (d) accrued interest on long-term debt, and (e) deferred compensation.

9. This item represents the income or loss reports by a company after expenses and losses have been subtracted from all revenues and gains for the fiscal period, including extraordinary items and discontinued operations.

10. This item represents the total amount of cash dividends for both common and preferred stock. This item includes (a) arrears from prior years paid in the current year, (b) cash paid in lieu of fractional shares, (c) dividends paid by companies acquired using the pooling of interest method, (d) liquidating dividends or distributions, (e) partnership distributions, and (f) subchapter S distributions. This item excludes (a) cash value of stock dividends, (b) dividends in kind (other than cash), (c) minority shareholders’ dividends, (d) patronage dividends, and (e) preferred requirement paid in common stock.

11. In fact, using CRSP data, we were able to check back to 1962 and found that no repurchases occurred.

12. The information-revelation function of dividend payments is examined theoretically and/or empirically in numerous studies, including Watts (1973), Brickley (1983), Kalay and Loewenstein (1986), Asquith and Mullins (1983), Healy and Palepu (1988), Kumar (1988), Lang and Litzenberger (1989) and Baja and Vijh (1990, 1995).

13. Dividend initiations have been studied in Asquith and Mullins (1983) and Healy and Palepu (1988) whereas Healy and Palepu (1988), and Michaely, Thaler, and Womack (1995) examine 
dividend omissions. The classic empirical study of the market response to dividend changes is Aharony and Swary (1980), with later such studies including Ofer and Siegel (1987).

14. Standard event study methodology was used to estimate the unexpected return and test statistics. See Brown and Warner $(1980,1985)$ for a detailed explanation of event study methodology.

15. It should be noted that with asymmetric information, dividends can also be viewed as bad news: Firms that pay out dividends are the ones without positive NPV projects to invest in. 


\section{REFERENCES}

Aharony, J., \& Swary, I. (1980). Quarterly dividend and earnings announcements and stockholders’ returns: An empirical analysis. Journal of Finance, 35(1), 1-12.

Asquith, P., \& Mullins, D. W., Jr. (1983). The impact of initiating dividend payments on shareholders' wealth. Journal of Business, 56(1), 77-96.

Bajaj, M., \& Vijh, A. (1990). Dividend clienteles and the information content of dividend changes. Journal of Financial Economics, 26, 193-219.

Bajaj, M.,\&Vijh, A. (1995). Trading behavior and the unbiasedness of the market reaction to dividend announcements. Journal of Finance, 50, 255-279.

Bernheim, D., \&Wantz, A. (1995). A tax-based test of the dividend signaling hypothesis. American Economic Review, 85(3), 532-551.

Bhattacharya, S. (1979). Imperfect information, dividend policy, and "the bird in the hand" fallacy. Bell Journal of Economics, 10(1), 259-270.

Brennan, M. J., \& Thakor, A. V. (1990). Shareholder preferences and dividend policy. Journal of Finance, 45(4), 993-1019.

Brickley, J. (1983). Shareholders wealth, information signaling, and the specially designated dividend: An empirical study. Journal of Financial Economics, 12, 187-209.

Brown, S., \&Warner, J. (1980). Measuring security price performance. Journal of Financial Economics, 8, 205-258.

Brown, S.,\&Warner, J. (1985). Using daily stock returns: The case of event studies. Journal of Financial Economics, 14, 3-31.

Charest, G. (1978). Dividend information, stock returns and market efficiency—II. Journal of Financial Economics, 6, 297-330.

Easterbrook, F. H. (1984). Two agency-cost explanations of dividends. American Economic Review, 74(4), 650-659. 
Healy, P. M., \& Palepu, K. G. (1988). Earnings information conveyed by dividend initiations and omissions. Journal of Financial Economics, 21(2), 149-176.

Jensen, M. C. (1986). Agency costs of free cash flow, corporate finance, and takeovers. American Economic Review, 76(2), 323-329.

Jensen, M. C.,\&Meckling,W. H. (1976). Theory of the firm: Managerial behavior, agency costs and ownership structure. Journal of Financial Economics, 3(4), 305-360.

John, K., \& Williams, J. (1985). Dividends, dilution, and taxes: A signaling equilibrium. Journal of Finance, 40(4), 1053-1070.

Kalay, A., \& Loewenstein, U. (1986). The information content of the timing of dividend announcements. Journal of Financial Economics, 16, 373-388.

Kumar, P. (1988). Shareholder-manager conflict and the information content of dividends. Review of Financial Studies, 1, 111-136.

Lang, L.H.P.,\&Litzenberger,R.H. (1989). Dividend announcements: Cash flow signaling vs. free cash flow hypothesis. Journal of Financial Economics, 24, 181-192.

Lintner, J. (1956). Distribution of incomes of corporations among dividends, retained earnings, and taxes. American Economic Review, 46(2), 97-113.

Litzenberger, R.,\& Ranaswamy, K. (1979). The effects of personal taxes and dividends on capital asset prices: Theory and empirical evidence. Journal of Financial Economics, 7, 163-195.

Miller, M., \& Modigliani, F. (1961). Dividend policy, growth and the valuation of shares. Journal of Business, 34, 411-433.

Miller, M.,\&Rock, K. (1985). Dividend policy under asymmetric information. Journal of Finance, 40(4), 1031-1051.

Miller, M.,\&Scholes, M. (1978). Dividends and taxes. Journal of Financial Economics, 6, 264-333.

Myers, S. C. (1977). Determinants of corporate borrowing. Journal of Financial Economics, 5(2), 147175. 
Myers, S. C., \& Majluf, N. S. (1984). Corporate financing and investment decisions when firms have information that investors do not have. Journal of Financial Economics, 13(2), 187-221.

Ofer, A. R., \& Siegel, D. R. (1987). Corporate financial policy, information, and market expectations: An empirical investigation of dividends. Journal of Finance, 42(4), 889-911.

Petit, R. R. (1972). Dividend announcements, security performance, and capital market efficiency. Journal of Finance, 27(5), 993-1007.

Watts, R. (1973). The information content of dividends. Journal of Business, 46(2), 191-211.

Yoon, P. S., \& Starks, L. (1993). Signaling, investment opportunities, and dividend announcements. Review of Financial Studies, 8(4). 
Table 1. Average Financial Characteristics of the Lodging Industry and the Standard and Poor's 500 (S\&P500) Market Portfolio

\begin{tabular}{lrrrrr}
\hline & \multicolumn{2}{c}{ Lodging } & & \multicolumn{2}{c}{ S\&P500 Market Porttolio } \\
\cline { 2 - 3 } \cline { 6 - 7 } Financial Characteristic & \multicolumn{1}{c}{$\%$} & \multicolumn{1}{c}{$S D$} & & & \multicolumn{1}{c}{ SD } \\
\hline Dividend payout & 7.30 & 10.62 & & 49.88 & 2.17 \\
Capex/asset ratio & 11.17 & 4.27 & & 3.65 & 0.14 \\
Net income/asset & 2.60 & 4.33 & & 2.93 & 0.08 \\
Debt/asset ratio & 36.90 & 6.16 & & 15.60 & 0.76 \\
\hline
\end{tabular}

Note: The averages for the lodging industry were computed across companies by year and then across the years so that the numbers would be comparable to those of the S\&P500 market portfolio. 
Table 2. Lodging Dividend Initiations: Average Excess Returns for Lodging Companies That Announced a Dividend Initiation.

\begin{tabular}{lccc}
\hline & \multicolumn{3}{c}{ Day Relative to the Announcement Date } \\
\cline { 2 - 4 } & -1 & 0 & +1 \\
\hline Excess return (\%) & 2.46 & 1.96 & 1.30 \\
$t$ statistic & 1.62 & 2.17 & 1.88 \\
\hline
\end{tabular}


Table 3. Lodging Dividend Increases: Average Excess Returns for Lodging Companies That Announced a Dividend Increase.

\begin{tabular}{lccc}
\hline & \multicolumn{3}{c}{ Day Relative to the Announcement Date } \\
\cline { 2 - 4 } & -1 & 0 & +1 \\
\hline Excess return $(\%)$ & -0.30 & 0.625 & -0.064 \\
$t$ statistic & -0.78 & 1.78 & -0.59 \\
\hline
\end{tabular}


Table 4. Average Financial Characteristics of Dividend- Versus Nondividend-Paying Companies in the Lodging Industry

\begin{tabular}{lcc}
\hline & \multicolumn{2}{c}{ Lodging } \\
\cline { 2 - 3 } & Dividend Paying & No Dividends \\
\hline Total assets (\$ million) & 876.62 & 90.09 \\
$S D$ & 490.32 & 79.12 \\
Net income/asset (\%) & 7.26 & 0.30 \\
$S D$ & 2.34 & 5.85 \\
Capex/asset ratio (\%) & 13.32 & 10.21 \\
$S D$ & 4.99 & 6.43 \\
Debt/asset ratio (\%) & 35.63 & 37.64 \\
$S D$ & 6.92 & 6.57 \\
\hline
\end{tabular}

Note: The averages were computed across companies by year and then across the years. 